\title{
Clinton administration blows cool on US involvement in Europe's LHC
}

Washington. Hopes that the United States will help to fund the construction of the Large Hadron Collider (LHC) at the European Laboratory for Particle Physics (CERN) in Geneva received a jolt last week when President Bill Clinton's science adviser, John Gibbons, failed to back the idea in a presentation to Congress.

High-energy physicists have been hoping that, following the cancellation of the Superconducting Super Collider (SSC) in Texas last October, the way had been opened up for greater US involvement in the LHC. They were therefore shocked when Gibbons failed to mention CERN by name in his testimony to a hearing of the House science subcommittee chaired by Rick Boucher (Democrat, Virginia).

According to congressional staff, the hearing had been intended to explore options for US participation in the LHC. But Gibbons instead appeared to suggest that the United States should lead a multinational effort to build an even more powerful accelerator at some future date. "Eventually a new facility will be needed," he said, after promising to maximize the use of existing US accelerators. "It should be a multinational effort, and the US should adopt a leadership role."

Asked by Sherwood Boehlert (Republican, New York) about the "conspicuous absence of any reference" to CERN in his testimony, Gibbons said it was of "no significance". But he added that attaching the future of US particle physics to CERN would be "to tie it solely with Europe, which would not be good for either party at this stage".

Despite Gibbons' denials, congressional staff are concerned that his reluctance to make any commitment to CERN will make it impossible to strike a deal with the laboratory's European members, and persuade a deeply sceptical Congress to accept it.

They fear that Gibbons may be softening up the high-energy community for budget cuts - not just in next week's budget for the 1995 financial year, but in succeeding years as well - as the importance of the field is reassessed in the wake of the SSC's demise.

Physicists told Boucher's subcommittee that formal US participation in the LHC was vital for the future of US high-energy physics, and would cost between $\$ 500$ million and $\$ 1$ billion over ten years.

John Peoples, director of the Fermi Laboratory, said he estimated that US participation in CERN would cost around $\$ 300$ million for the construction of the LHC, and $\$ 200$ million for detector work. Frank Merritt of the University of Chicago said the cost of supporting physicists working at CERN would be between $\$ 50$ and $\$ 60$ million per year, while an "appropriate level of [US] support" for CERN's overall costs would be between $\$ 30$ and $\$ 40$ million.

A subgroup of the Department of Energy's High Energy Physics Advisory Panel (HEPAP) will report in the spring on what priority such an investment should have in the department's $\$ 620$ million budget for high-energy physics.

Boehlert, one of the leaders of the congressional campaign against the $\mathrm{SSC}$, is one of several subcommittee members now keen to support US participation in CERN. But the position of Joe Barton (Republican, Texas) may be more representative of Congress as a whole.

"This congressman is going to look very sceptically - very sceptically - at us trotting over to Europe, given that they have done absolutely nothing to help with what was the biggest high-energy physics project in the world," said Barton. "I never saw one mark, frank or pound coming to this side of the ocean [for the SSC]."

Administration officials sympathetic to CERN say that such views can be overcome only if top officials such as Gibbons and Hazel O'Leary, the Secretary of Energy, strongly support the collaboration and sell it hard to Congress.

Martha Krebs, director of energy research at the Department of Energy, held her first meeting with Chris Llewellyn-Smith, the director of CERN, last Saturday, 29 January, when both were in California. Krebs says that "internal discussions" in her department have looked at various options for involvement in CERN.

These options include full membership, associate membership or some form of bilateral partnership. But Krebs says that no official discussions have yet taken place. "It's something we are just beginning to pull together," she says.

There will clearly be no money for CERN participation in the budget for fiscal year 1995, which begins on 1 October. Gibbons says consideration will be given to including such money in the budget for fiscal year 1996, once the HEPAP panel has delivered its report, and the president's new National Science and Technology Council (NSTC) has considered the matter.

But it seems unlikely that the NSTC will want to increase the United States' annual expenditure on high-energy physics. And even if HEPAP makes collaboration with CERN a higher priority than existing, USbased facilities such as Fermilab, it is hard to see what the Energy Department, the administration or Congress would have to gain from transferring money from these US facilities to Europe.

\section{Academy hotel deal reaps hidden rewards}

Moscow. Suspicions that the Russian Academy of Sciences may not have been entirely open about the details of the recent sale of property in the centre of Moscow have been heightened by the discovery of a safe containing almost US\$1 million in one of the academy's former buildings.

Several years ago, the praesidium of the academy reached agreement with a German company to build the five-star Palace Hotel on the site of a hotel then operated by the academy.

The new hotel was subsequently completed. But no details have been published of how much money was received by the academy, nor of how the money was used. Even the organization that formally owned all the academy's property Goskomimushchestvo - is said to have been kept in the dark.

According to a report in the newspaper Segodnya, government tax investigators recently visited the Palace Hotel to carry out an audit, and discovered $\$ \mathbf{8 6 0 , 0 0 0}$ in one of the hotel's safes which could not be accounted for.

The money was apparently confiscated, but, according to the newspaper, the Prime Minister, Viktor Chernomyrdin, received a letter from the presldent of the academy, Yuriy Osipov, asking for its return.

Osipov: wants the money back.

There is uncertainty in Moscow about how far the issue will be pursued. An investigation into the origins of the money was launched by Yegor Gaidar, the former first deputy prime minister and leading reformer. But following his resignation, the consequence of the poor showing of reformers in the recent elections, it will now be up to Chernomyrdin - who is on close terms with Osipov - to decide what to do next. Vladimir Pokrovsky 